\title{
INTERNATIONAL TREATY ON PLANT GENETIC RESOURCES FOR FOOD AND AGRICULTURE AS A BASIS FOR LIMITING INTELLECTUAL PROPERTY OF PLANT BREEDERS IN SERBIA
}

\author{
Janko Veselinović ${ }^{1}$, Mirjana Milošević2, Sara Počuča ${ }^{3}$
}

\begin{abstract}
It is widely accepted that new plant varieties are protected as a form of intellectual property. Serbian legislation and international conventions protect new plant varieties, either through sui generis protection or by patent rights. However, International Treaty on Plant Genetic Resources for Food and Agriculture, also signed by Serbia, has endangered the rights of plant breeders in Serbia, because the greatest number of plant varieties in Serbia is not protected as intellectual property. On the other hand, the Treaty offers the possibility to natural and legal persons from other signatory countries to use new plant varieties of Serbian plant breeders. Seeing as the varieties are not protected, there is a possibility for the plant breeders' rights to be endangered. The goal of this paper is to try and consider the legal consequences, answering certain open questions regarding the protection of intellectual property in this field. A method of parallel comparison was used.
\end{abstract}

Key words: international agreement, plant varieties, intellectual property, plant breeders, Serbia.

JEL: $M 43,012$

\section{Introduction}

Creation of new plant varieties is a long and complex process which entails great effort, knowledge and financial investments. Such creation requires scientific knowledge in the field of genetics, plant breeding, molecular biology, biometrics, as well as a great experience and entire intellectual knowledge of the breeder who creates a new variety. In order for the

1 Janko P. Veselinović, Ph.D., Assistant Professor, University in Novi Sad, Faculty of Agriculture, Department of Agricultural Economics and Village Sociology, Square Dositeja Obradovića 8, 21000 Novi Sad, Serbia, Phone: +381 21450 355, E-mail: veselinovic.janko@gmail.com

2 Mirjana Milošević, Ph.D., Full professor, University in Novi Sad, Faculty of Agriculture, Square Dositeja Obradovića 8, 21000 Novi Sad, Serbia, Phone: +381 21450 355, E-mail: mirjana.milosevic9@gmail.com

3 Sara Počuča, M.A., Ph.D. student, Faculty of Law, Belgrade University, Blvd. Kralja Aleksandra no. 67, 11000 Belgrade, Phone: + 38163209 523, E-mail: pocucamsara@gmail.com

EP 2014 (61) 1 (211-223) 
breeders (or those enjoying such legal rights) to not remain without an adequate financial remuneration for the expenses incurred during the creation of new varieties, it is necessary for the new plant variety to be protected as intellectual property. This means that breeders, along with creating new plant varieties, must also work on their protection as intellectual property. Most often, it takes more than ten years of use of a new variety to compensate for the expenses for its creation and legal protection. If it is used without authorisation, the entire multidisciplinary results are brought into question.

Legal regulation of this field in Serbia was necessary from the aspect of the Serbian plant breeders, but also for the legal security of those abroad who might want to enter the Serbian market with their products. The most significant source of legal regulation of this field in Serbia is the Law on Protection of Breeders of Plant Varieties (LPBPV). An integral part of the Serbian legal system is also the International Convention on Protection of New Plant Varieties, passed by The International Union for Protection of New Plant Varieties (UPOV), ratified by the republic of Serbia in 2010, as well as the International Treaty on Plant Genetic Resources for Food and Agriculture, ratified in the early 2013. The Regulation of the European Council (REC) created a system for the protection of plant varieties as one and only form of industrial property rights for new plant varieties in the European Union, managed by The Community Plant Variety Office - CPVO. CPVO seat is in Angers, France.

The goal of this paper is to try and consider the legal consequences, answering certain open questions regarding the protection of intellectual property in this field.

\section{Plant resources as a common concern of all countries}

Apart from the fact that it is necessary to protect the plant breeders' rights and to enable them to enjoy the rights on national and international levels, there is a legal framework which limits those rights in certain cases. On a national level, the obligatory licence is a sort of state intervention in the plant breeder's right to freely manipulate and deal with a plant variety. The obligatory licence is defined by the Law on Protection of Plant Breeders' Rights (article. 31-35.) and can be issued by the competent minister if the holder of the plant breeder's rights refuses to yield the right to use the protected variety to other persons or makes unjustified demands for such use. On the international level, the most significant legal source on this matter is the International Treaty on Plant Genetic Resources for Food and Agriculture (Official gazette of the Republic of Serbia, International treaties, no. 1/13).

This treaty has only recently (2013) become an integral part of Serbian legislative, after it was ratified by the National Assembly of the Republic of Serbia. Serbia had previously not ratified it for many years, as it also entails certain negative consequences for the holders of rights to registered and unregistered plant varieties.

The motives for the elaboration of this international agreement should also be emphasized. Its preamble emphasizes a "special nature of plant genetic resources for food and agriculture, their distinctive features and problems needing distinctive solutions"( UPOV, Preamble). It underlines the "alarm by the continuing erosion of 
these resources", pointing out that the plant genetic resources for food and agriculture are a common concern of all countries, seeing as all countries largely depend on plant genetic resources for food and agriculture that originate from another country. The contemporary world is being faced with huge issues in securing production of enough quantities of healthy safe food. It is thus explicitly stated that plant genetic resources must not be limited by country borders. The cited legal foundations for the passing of this Treaty are the goals of Rome Declaration on World Food Security and Action plan of the World Food Summit, as well as a sustainable agricultural development of the current and future generations, with the emphasis on "urgently strengthening the capacity of the developing countries and countries with transition economies for undertaking of such tasks" (UPOV Preamble). It is also emphasized that the global action plan of preservation and sustainable use of plant genetic resources for food and agriculture is an internationally confirmed framework of such activities.

One of the key provisions of the Preamble of this Treaty is "Affirming also that the rights recognized in this Treaty to save, use, exchange and sell farm-saved seed and other propagating material, and to participate in decision-making regarding, and in the fair and equitable sharing of the benefits arising from, the use of plant genetic resources for food and agriculture, are fundamental to the realization of Farmers' Rights, as well as the promotion of Farmers' Rights at national and international levels" (UPOV Preamble). The Preamble especially underlines the fact that the states, in realising their sovereign rights over their plant genetic resources for food and agriculture, might find use in creating an efficient multilateral system for facilitated access to a part of these resources that would be defined by agreements, as well as for a just and equal share of benefits arising from their use.

Already in the very Preamble of International Treaty on Plant and Genetic Resources for Food and Agriculture it can be seen that there is a "higher" interest above the right of the countries to protect their genetic resources for food and agriculture - the interest of availability of those resources to the rest of the humanity, especially the developing countries. It can be clearly understood that countries which generate the largest plant genetic resources regardless of the obligation to make them useful for their own people, also have a responsibility to other nations without such resources. Countries with large populations, especially African ones, do not have a significant potential for creating such resources, but, on the other hand, have greatest problems with feeding their population. From the ethical point of view, this international Treaty is fully justified.

\section{Legal and economic consequences for Serbian agriculture owing to the implementation of International Treaty on plant genetic resources for food and agriculture}

The crucial question is whether certain provisions of the International Treaty on Plant Genetic Resources for Food and Agriculture can be "legally" abused by large multinational companies, which can get hold of these resources, especially those unprotected as intellectual property. National interests of Serbia can be particularly brought into question, seeing as Serbian companies that deal in creating plant genetic resources are state-owned 
and directly referred to by this Treaty, while almost all significant companies dealing in seed production abroad are private companies and have a special status in this Treaty. The contemporary world is being faced with huge issues in securing production of enough quantities of healthy safe food (Nešković, 2012). Apart from favourable conditions (land, climate, and so on), producers' traditional habits have to the greatest extent had an impact on the unjustifiably high presence of wheat and corn in the structure of crop production (Stevanović et al., 2012).

The question to be asked is whether it is accidental that this Treaty, existent since 2001, has been ratified by Serbia as late as twelve years afterwards. International Treaty on Plant Genetic Resources for Food and Agriculture was signable in the Food and Agriculture Organisation (FAO) of the United Nations, from November $3^{\text {rd }} 2001$ to $4^{\text {th }}$ November 2002 for all FAO member countries and those which are not, but belong to the UN or any of its specialised agencies or International Atomic Energy Agency. Treaty is subject to ratification. The treaty enters into force on the ninetieth day after the deposit of the fortieth instrument of ratification, acceptance, approval or accession, provided that at least twenty instruments of ratification, acceptance, approval or accession have been deposited by Members of FAO. A special dilemma is whether everything has been done to prevent the possible harmful consequences of this Treaty. This is especially true when taking into account that Serbia has two Institutes which create new plant varieties and which are significant on a worldwide level, Institute of Field and Vegetable Crops from Novi Sad and Institute for Corn, Zemun Polje, Belgrade.

It is important that Serbia, with significant potentials of new plant varieties, can significantly contribute in the created system of multilateral exchange, according to the ratified Treaty. Thus, this Treaty will place significant burden of helping the undeveloped countries on Serbian plant breeders. The countries which are more developed than Serbia, having protected their plant varieties, are not in such position and are not threatened by endangering of protected intellectual property. The degree of the damage could be assessed depending on the number of Serbian plant varieties to be economically exploited without an adequate remuneration and the number of rights to plant varieties lost by Serbian breeders if some are falsely declared as breeders.

Numerous experts in this field, both the plant breeders and respectable lawyers acquainted with the circumstances in plant variety protection have indicated the potential problems that the ratification of the Treaty could cause. Most of them have suggested delaying the passing of the Law on Acceptance of International Treaty on Plant and Genetic Resources for Food and Agriculture for several years in order to leave time for the protection of domestic plant varieties. "Delay is necessary to pass and apply the regulations on founding of the National "bank" of genetic resources and define the conditions for a potential exchange of such resources" ${ }^{4}$, as stated in the announcement of the Serbian Green party, which has experts in these topics, as well. All who share this attitude agree on the fact that a delay in such moment would have been a chance that should not have been missed,

4 “Zeleni Srbije za zaštitu domaćeg semena“, „Zelena Srbija“ http://www.rtv.rs/sr_lat/ drustvo/zeleni-srbije:-zastitimo-domace-seme_367016.html 
in order for the breeders of Serbian plant varieties to register and protect their seed with the Government's help. This would secure the right for further protection within the potential exchange, as well as a division of profit in the case of commercialisation by the participants of resource exchange. Unfortunately, the competent ministry and the Government had no understanding for such initiatives.

Serbia is seriously lagging behind in the sphere of protection of plant varieties, primarily due to wars and the crisis that ensued after 1990 and lasted more than a decade. During this period, other countries worked on creation and protection of new plant varieties. For most countries in the European Union the protection of new plant varieties started in 1996, when 1386 were protected. The trend of protection grew, so in 2008 the number of protected plant varieties reached 3012..$^{5}$ The creation of a plant variety and its protection is a significant investment. According to an analysis, for the creation of a variety of wheat in Czech Republic in 2002, about 2.5 million dollars were used. A certified wheat variety was sown on about 100,000 hectares there, while the same amount was sown with an uncertified wheat seed. If one considers that 20 USD is a yearly profit from a hectare sown with a certified seed, a total yearly sum of 200,000 USD is obtained. Hence, it takes twelve years for the invested resources to yield profit (Krehilk, 2003).

In the European Union and USA, the number of varieties submitted for protection is great. Special care about the protection of rights of plant breeders is taken in the USA. As an example, the number of protected varieties of cotton since 1970 can be used. Since 1980, the number of created and protected varieties has been parallel. This means that the number of unprotected sorts was negligible. The situation is similar with other plant varieties. The situation in Serbia is very different. The number of protected sorts is negligible.

The analysis of the most significant provisions of the Treaty indicates the provisions that could be questionable from the point of view of protection of the breeders of domestic plant varieties. Our starting points are three facts that are important for Serbian plant breeders. The first one is that in Serbia there is a significant number of plant breeders with their own national and commercial value and potential. Second, major plant breeders or holders of rights are national institutes and certain varieties, albeit new, are not adequately legally protected. Third, by adopting the international Treaty, an obligation is created for the plant breeders to make the varieties available under the conditions in the Treaty, not only to the developing countries, but also indirectly, to all multinational companies which might, taking into account what has previously been mentioned, "legally" abuse it.

An important question should be asked - why has Serbia ratified this Treaty before circumstances were made for the plant genetic resources to be protected. It is known that the protection of intellectual property is an expensive process and that several thousand plant varieties is not protected as intellectual property, although they are a fruit of effort of Serbian experts. Our institutes needed additional time and significant financial support in order to protect plant genetic resources.

5 UPOV publication, http://www.upov.int/export/sites/upov/en/documents/c/43/c_43_12.pdf EP 2014 (61) 1 (211-223) 
In the introductory part of the Treaty, its goal is emphasized and defined as "conservation and sustainable use of plant genetic resources for food and agriculture and the fair and equitable sharing of the benefits arising out of their use (UPOV), in harmony with the Convention on Biological Diversity, for sustainable agriculture and food security."

The contractual provisions of the Treaty oblige the signatory countries to "survey and inventory plant genetic resources for food and agriculture, taking into account the status and degree of variation in existing populations, including those that are of potential use and, as feasible, assess any threats to them" (UPOV, General Obligations, Article 5, Paragraph 1a). Obligatory duties on the national level were defined as: strengthening of international activity with the aim to promote preservation, evaluation, documentation, genetic strengthening, plant breeding, seed multiplication and sharing by enabling access and exchange in accordance with the Treaty on Plant Genetic Resources for Food and Agriculture of certain information and technology. What can be recognized here is the obligation of the Serbian breeders to enable access to plant varieties that are, unfortunately, not yet adequately legally protected.

In the article in which the multilateral system of access to and participation in sharing is covered, the starting principle is that "the Contracting Parties recognize the sovereign rights of States over their own plant genetic resources for food and agriculture, including that the authority to determine access to those resources rests with national governments and is subject to national legislation." (UPOV, Multilateral system of a access and benefitsharing, article 10.) However, the next paragraph points out that "In the exercise of their sovereign rights, the Contracting Parties agree to establish a multilateral system, which is efficient, effective, and transparent, both to facilitate access to plant genetic resources for food and agriculture, and to share, in a fair and equitable way, the benefits" A Special annex (UPOV, Annex 1 of the Treaty) establishes the list of crops included in the multilateral system. The list contains all more significant crops, fodder, and grass. The most debatable part, from the aspect of national economy, is the provision which stipulates what plant genetic resources for food and agriculture the Treaty refers to, from the aspect of the right holder. Namely, it is emphasized that those are resources which are "under rule and control of signatory parties and public sector domain." The essential fact is that all significant resources in this field in Serbia are under the control of the state, in the public sector domain. This means that the domestic plant genetic resources have become, by means of ratification of this Treaty, available to users outside Serbia, not only to those who are in public sector and under the control of the state, but also to the public companies dealing with plant varieties and plant genetic resources in general. On the other hand, "other owners of plant and genetic resources" for food and agriculture, signatories of the Treaty are "obliged" to "include those plant and genetic resources for food and agriculture in the multilateral system (UPOV, Annex 1, of the Treaty). In other words, the right bearers who own plant and genetic resources for food and agriculture and are under the control of the state must make those resources available to all signatory parties, while the companies which are not of such nature do not have to. In that case, they are merely encouraged to do so. 
The Treaty defines the obligations of its signatories to take measures for facilitated access to plant genetic resources for food and agriculture and, in accordance with that, undertake legal or other necessary measures in order to secure such access to the others. It is stipulated that, with that purpose, such access is to be provided to "natural and legal persons under the Jurisdiction of any Contracting party" (UPOV, Article 12.3.). This practically means that Serbian institutes are obliged to provide access to their genetic resources for food and agriculture to any individual, regardless of whether that individual comes from Austria, USA, Russia or China. Apart from that, it is stipulated that such access must be granted "Access shall be accorded expeditiously, without the need to track individual accessions and free of charge, or, when a fee is charged, it shall not exceed the minimal cost involved" (UPOV, Article 12.3.b) This also entails that "all available passport data and, subject to applicable law, any other associated available non-confidential descriptive information, shall be made available with the plant genetic resources for food and agriculture provided" (UPOV, Article 12.3.c).

In the Article 12.3.d of the Treaty, it is stipulated that the recipients shall not claim any intellectual property or other rights that limit the facilitated access to the plant genetic resources for food and agriculture, or their genetic parts or components. This does not represent a special protection for genetic resources that are not protected, seeing as it is not possible to control the "fate" of the new varieties, which is especially true of corn, sunflower and such.

The contract does not directly refer to plant genetic resources protected by the intellectual and other property rights, so the Treaty states that access to them shall be "in accordance with the relevant international agreements and national laws."

Seeing as it is presumed that less than $1 \%$ of plant varieties/genetic resources in the field of agriculture in Serbia are protected by intellectual property rights, it becomes clear that these national resources have remained virtually unprotected. In developed western countries, plant genetic resources in this field are almost entirely protected.

Taking into account the aforementioned circumstances, one could ask what the possibilities to pull out of this Treaty are if it's harmful consequences to Serbian agriculture and food production are confirmed. The foreseen possibility is that "any Contracting Party may at any time after two years from the date on which this Treaty has entered into force for it, notify the Depositary in writing of its withdrawal from the Treaty" (UPOV, Withdrawals, Article 32.). However, withdrawal is valid one year from the date of acceptance of written notification. This practically means that if Serbia, taking into account its recent signing of the Treaty, would immediately file for withdrawal from the Treaty, that withdrawal would come into force only in three years' time. Two years until the date of coming into force of the Treaty for Serbia and one year from the date of receiving a written notification of withdrawal.

Naturally, until that time Serbia would be obliged to fulfil all obligations from the Treaty, so it is questionable what consequences the withdrawal would bring. 


\section{"Farmers' privileges" as an exception from the inviolability of interests of plant breeders}

International Treaty on plant Genetic Resources for Food and Agriculture and International Convention on the Protection of new Plant Varieties can be a subject of comparison. If we presume that a plant variety is protected as intellectual property, it means that collectioner/ plant breeder has certain rights over the reproductive and harvested material of his varieties. To be true, other breeders are also given the right to use protected varieties for the development of the new ones, with no obligation whatsoever to the original breeder. This convention also foresees the so-called "farmers" privilege" stating that contracting parties can limit breeders' rights within sensible boundaries and with preservation of legal interests of the breeder in order to allow the agricultural producers to use (on their farms and in multiplication purposes) the harvested material of a protected sort obtained on their farms (farm-saved seed), (Šarac, 2006). "Farmers' privilege" is a legal possibility for the farmer to reuse the seed of the protected variety, although it was protected as intellectual property.

The Law on protection of plant varieties as well as the aforementioned Convention create a privilege and a legal precedent. Farmers are thus allowed to do something bypassing the basic rules of protection of varieties as intellectual property. However, as we have pointed out, the Convention guarantees certain exclusive rights on planting material, so the farmers are often forced to contractually bind not to use the seed produced on their farms for the next year's sowing. Thus, farmers are prevented from using the "farmers' privileges."

When it comes to the application of the "farmers' privilege" on the territory of the European Union, its legal foundation is the regulation EU 88/44/EC. According to the regulation, the farmers can freely use the seeds of protected varieties, while the product of plant material is unprotected. Farmers are, however, not allowed to resell patented seeds (Milošević, 2012).

Farmers' privileges can be completely abolished and, along with them, the use of farm-saved seed. It is possible that through the domination of the patent right doctrine the holder of intellectual property rights obtains an unlimited right to control all profit gained from a variety. This opens the question of whether in future there can be a discontinuation of possibility to use farm-saved seed in certain countries. There is a tendency for the next change of Convention for the Protection of New Varieties of Plants to include the prohibition or significant limitation of use of farm-saved seed. The legislative of certain countries has already regulated that. In theory, there will still remain an option for the farmers to make arrangements with various licence holders, which is not the case with patent protection. In practice, it is very probable that companies will not denounce their acquired rights to control all seed. That trend is going to grow, thus increasing the profit of companies (Milošević, 2012). The farmers' privilege is debatable, both from the legal and economical point of view. Namely, it remains an exception from the basic rule that property is inviolable, which includes the intellectual one, as well. On the other hand, the seed industry, represented by its owners, wish to control who produces seed as well as the seed market. Seeing as a significant part of the world production of food is still based on farm-saved seed (as the product of farmers' privileges), the seed industry works on creating a legal system which will limit, or even completely abolish, such use 
(Milošević, 2012). It is done through World Trade Organisation, but also through bilateral trade agreements or direct lobbying of the governments. Governments of numerous countries already insist on being sent data on the quantity of seed multiplied at farms. It is the first step towards the restriction of use of seed of protected varieties at farms.

The most drastic example, which is in direct opposite with the spirit of the International Treaty on Plant and Genetic Resources for Food And Agriculture is the application of the so-called "terminator technology". It is not forbidden by the Convention for the Protection of New Varieties of Plants. More precisely, it is allowed as a form of protection of intellectual property. This technology foresees that genetic engineering is used to implant the plant with a mechanism that destroys the plant of the next generation. The company Delta and Pene Land Co was granted a US patent 5,723,765 in 1998 for the Technology Protection System (Radin, 1999). There are many opponents to the application of this technology. In this example, two key principles collide. The first one is the inviolability of all forms of property, including intellectual. The second principle is that plant genetic resources for food and agriculture are a common concern of all countries, seeing as all countries largely depend on plant genetic resources for food and agriculture which originate from another country. If the theory of this discrepancy is analysed, the question remains of the situation of plant variety breeders in Serbia. Not only do they not apply the so-called terminator technology, but have in a very small percentage protected the rights on new plant varieties as a form of intellectual property. In addition to that, according to the International Treaty on Plant Genetic Resources for Food and Agriculture, the mentioned plant varieties must be made available to every natural and legal person from any signatory country. It should be recalled that one of the strategic directions of the former federative state (Socialist Federative Republic of Yugoslavia) was the development of seed production and creation of own plant varieties. Only in the period between 1960 and 1997, the Yugoslav breeders have protected more than a thousand newly-created plant varieties, many of which are among the leading ones in the world according to quality and yield (Šarac, 2006). An interesting piece of data is that an initial gene fund of 58 collections with about 32.000 samples was created between 1982 and 1992, for the need of the national Bank of plant genes within the programme of protection of biodiversity and preservation of genetic resources (Kišgeci, 1997). The consequence of the dissolution of the former state was also the devastation of the domestic agricultural production and the decrease of investment in breeding of plant varieties. In recent years the state has improved, but, unfortunately, there are not enough resources for the protection of new plant varieties as intellectual property.

A very important warning comes from anti-globalists, whose criticisms are aimed primarily at multinational companies. Thus, according to Karen Lejman and Al Krebs, multinational companies are, for the first time, at the verge of taking control over genetic wealth of the planet through the global legal framework defined by the World Trade Organisation (Lejman et al., 2003). The same authors state that five hundred thousand Indian farmers demonstrated against GAT on October $2^{\text {nd }} 1993$, swearing to protect their right to produce and keep their seed. They made a charter of farmers' rights, among which the special place was occupied by the right to keep, reproduce and change the seed and the plant.

EP 2014 (61) 1 (211-223) 


\section{Division of benefits}

Pertaining to this is also the question of participation in the division of benefits in the Multilateral System of Exchange of Plant Genetic Resources for Food and Agriculture. It is established by the Treaty that the benefits arising from use, including commercial one, of plant genetic resources for food and agriculture within the Multilateral System "shall be shared fairly and equitably through the following mechanisms: the exchange of information, access to and transfer of technology, capacity-building, and the sharing of the benefits arising from commercialization, taking into account the priority activity areas in the rolling Global Plan of Action, under the guidance of the Governing Body"(UPOV, Chapter: Benefit Sharing in the Multilateral System, Article 13.2). A good intention of the author of the Treaty could be recognised here. It could be confirmed by the fact that a socalled "mechanism" is formed with a special (trustee) account to receive and use financial resources, which will flow in in order to realise this agreement. This means that the recipient who commercialises a plant variety (plant genetical resource) transfers to that account "an equitable share of the benefits arising from the commercialization of that product."(UPOV, 13.2.d(ii). This obligation is inexistent or turns into a recommendation in the case that the product is available to others without limitations, for the purpose of further research and breeding, in which case the recipient who commercialises shall be encouraged to make such payment.

The Governing body defines, at the first meeting, a level, form and means of payment in accordance with the commercial practice. A framework is also defined, according to which the division within the multilateral system will be made according to the principle of resources being distributed primarily, directly and indirectly to agricultural producers in all countries. This particularly refers to developing countries and countries with a transition economy which preserve and use in a sustainable way the plant genetic resources for food and agriculture. From the point of view in Serbia, such attitude is debatable, in the least. Seeing as Serbia is mostly going to be the giver of plant genetic resources for food and agriculture in this exchange and taking into account the fact that it had no resources to protect its plant varieties as intellectual property, the question is whether resources should be made available for such purpose within the multilateral system. Considering the specific position of Serbia in this case, we do not see it as possible. However, one provision of the Treaty offers certain chances for that. Namely, the article 13.3. of the chapter on participation in benefit-sharing in the Multilateral system stipulates that "the Governing Body shall, at its first meeting, consider relevant policy and criteria for specific assistance under the agreed funding strategy established under the article on financial resources (UPOV, Article 18.) for the conservation of plant genetic resources for food and agriculture in developing countries, and countries with economies in transition whose contribution to the diversity of plant genetic resources for food and agriculture in the Multilateral System is significant and/or which have special needs." Our country would certainly have the possibility to "clarify" its special nature and "special needs" through a concretisation of this provision, taking into account its recent accession. This is primarily so because one should be led by the fact that the percentage of legal protection of plant varieties is very low, as well as that there is a large fund of quality plant varieties. 


\section{Access to ex situ collections, technologies and exchange of information}

Apart from the fact that signatory countries are obliged by the provisions of the Treaty to enable access to their plant genetic resources, this act creates conditions to access ex situ collections. Ex situ collection denotes a collection of plant genetic resources for food and agriculture maintained away from its natural habitat.

The Treaty calls upon the international centres which keep the collections of plant genetic resources to make them available to the signatory parties of the Treaty. This primarily refers to the collections of plant resources for food and agriculture, safeguarded by the trustees - International Agricultural Research Centres (IARCs) and Consultative Group on International Agricultural Research (CGIAR). Plant genetic resources for food and agriculture must be made available in accordance with the provisions of the Treaty on material exchange, which is currently used in accordance with the agreement between International Agricultural Research Centres and Food and Agriculture Organisation of the UN.

It arises from this that Serbia can make its plant and genetic resources available on a twofold basis (from two collections). The first one is collections of domestic breeders in their own possession, the other is collections in International Agricultural Research Centres. If a plant breeder from Serbia submits a new plant variety for keeping to an International Agricultural Research Centre, the potential user can turn to either the breeder or the centre in order to obtain that plant variety.

The contracting parties are obliged to cooperate in developing and strengthening "to facilitate the exchange of information, based on existing information systems, on scientific, technical and environmental matters related to plant genetic resources for food and agriculture" (UPOV, Article 17). As a result of such exchange, it is expected that a significant contribution will be made to the sharing of benefits by making information on plant genetic resources for food and agriculture available to all Contracting Parties.

A part of the Treaty defines the access to not only the genetic material, but also the technology, as it is "Recognised that some technologies can only be transferred through genetic material" and stated that "the Contracting Parties shall provide and/or facilitate access to such technologies and genetic material. Access to these technologies, improved varieties and genetic material shall be provided and/or facilitated, while respecting applicable property rights and access laws, and in accordance with national capabilities." Access to and transfer of technologies, including those protected by intellectual property rights, was especially facilitated and for the least developed countries and countries with economy in transition.

\section{Conclusion}

By analysing the most important provisions of the International Treaty on Plant and Genetic Resources for Food and Agriculture it can be concluded that the application of a certain part of provisions could be legally and economically detrimental for Serbian plant breeders. The first 
reason for this is that in Serbia there are breeders of plant varieties which are globally important and have their own commercial value and potential. Second, the most significant breeders of plant varieties, right bearers are the national institutes, while certain varieties, although they have conditions for that are not protected as intellectual property. By implementing the International Treaty, plant breeders are obliged, under the conditions of the Treaty, to enable access to plant resources not only to developing countries, but, indirectly, to all multinational companies that might "legally" abuse it. Thus, unequal contracting parties are put in an equal position, making Serbian plant breeders yield up everything, while breeders in developed countries do not have such obligations. Seeing as no reserves are allowed, this Treaty requires the assessment of possible activities that would help preserve the plant resources of Serbia as international resources.

\section{Literature}

1. Council Regulation no. 2100/94 on Communitary Plant Variety Rights (1994), OJL 132, 2. 11. 1994., available at: www.wipo.int/edocs/lexdocs/laws/en/ee/ee119en.pdf

2. Kišgeci, J. (1997): Savezni zavod za biljne i životinjske genetičke resurse u sistemu zaštite biodiverziteta Jugoslavije, Savremena poljoprivreda, Novi Sad, Srbija, br. 1-2.

3. Krehilk, L. (2003): Zaštita biljnih sorti, Anthology, EESNET Meeting on Seed Industry and GMOs, Belgrade, Serbia, p. 117.

4. Lejman, K., Krebs, A. (2003): Kontrola nad svetskim zalihama hrane, in Mander Džeri, Goldsmit Edvard (ed.), Globalizacija - argumenti protiv, Beograd, Clio, Beograd, Srbija, p. 417.

5. Međunarodna konvencija o zaštiti novih biljnih sorti (1961), UPOV, Pariz 1961, Ženeva 1972, 1978, 1991, Zakonom o potvrđivanju međunarodne konvencije o zaštiti novih biljnih sorti, Službeni glasnik Republike Srbije, Međunarodni ugovori, br. 19/2010.

6. Međunarodni ugovor o biljnim genetičkim resursima za hranu i poljoprivredu, Službeni glasnik Republike Srbije, Međunarodni ugovori, br. 1/13.

7. Milošević, M. (2012): Zaštita biljne sorte kao intelektualne svojine, Semenarska asocijacija Srbije, Novi Sad.

8. Naseem, A., Oehmke, J. F., Schimmelpfennig, D. E. (2005): Does Plant Variety Intellectual Property Protection Improve Farm Productivity? Evidence from Cotton varieties, AgBio Forum, Journal of Agro biotechnology Management and Economics, vol. 8, no. 2-3, art. 6, pp. 100-107, available at: www.agbioforum.org/v8n23/v8n23a06-oehmke. $\underline{\mathrm{htm} \# \mathrm{~F} 2}$

9. Nešković, S. (2012): An agricultural production as a significant area of a strategy of economy diplomacy of Serbia, Economics of Agriculture, IAE, Belgrade, vol. 60, no. 4, pp. 589-602.

10. Radin, W. J. (1999): The technology Protection system: Revolutionary or evolutionary?, Biotechnology and Development Monitor, Amsterdam, the Netherlands, vol. 37, p. 217.

11. Šarac, J. (2006): Specifičnosti zaštite prava intelektualne svojine u oblasti biotehnologija, 
Singidunum revija, Univerzitet Singidunum, Belgrade, Serbia, vol. 8, no. 1, p. 355.

12. Stevanović, S., Đorović, M., Milanović, M. (2012): The development of the market production of cereals in Serbia: example wheat and corn, Economics of Agriculture, IAE, Belgrade, vol. 59, no. 3, pp. 617-632.

13.Zakon o zaštiti prava oplemenjivača biljnih sorti, Službeni glasnik Republike Srbije, br. $41 / 09$.

14.Zeleni Srbije za zastitu domaćeg semena, Zelena Srbija, available at: www.rtv.rs/sr_lat/ drustvo/zeleni-srbije:-zastitimo-domace-seme 367016.html

15. UPOV publication, no. 437, available at: www.upov.int/export/sites/upov/en/documents/ c/43/c 43 12.pdf

\title{
MEĐUNARODNI UGOVOR O BILJNIM GENETIČKIM RESURSIMA ZA HRANU I POLJOPRIVREDU KAO OSNOV ZA OGRANIČENJE INTELEKTUALNE SVOJINE OPLEMENJIVAČA U SRBIJI
}

\author{
Janko Veselinovićc ${ }^{6}$ Mirjana Miloševićc , Sara Počuča ${ }^{8}$
}

\begin{abstract}
Sažetak
Opšte prihvaćena je zaštita novih biljnih sorti kao oblik intelektualne svojine. I domaće zakonodavstvo i međunarodne konvencije štite nove biljne sorte, bilo kroz sui generis zaštitu ili kao patentno pravo. Međutim, Međunarodni ugovor o biljnim genetičkim resursima za hranu i poljoprivredu, koji je prihvatila i Srbija ugrozio je prava oplemenjivača u Srbiji, zbog toga što najveći broj biljnih sorti u našoj zemlji nisu zaštićene kao intelektualna svojina. Sa druge strane Ugovor pruža mogućnost fizičkim i pravnim licima iz drugih zemalja potpisnica da koriste nove biljne sorte srpskih oplemenjivača. Sobzirom da sorte nisu zaštićene postoji mogućnost ugrožavanja prava oplemenjivača. Cilj ovog radaje da pokuša da sagleda pravne posledice i da odgovore na pojedina otvorena pitanja koja se tiču zaštite intelektualne svojine u ovoj oblasti. Korišćen je uporedni metod.
\end{abstract}

Ključne reči: međunarodni ugovor, biljne sorte, intelektualna svojina, oplemenjivači, Srbija.

6 Doc. dr Janko P. Veselinović, Univerzitet u Novom Sadu, Poljoprivredni fakultet, Departman za ekonomiku poljoprivrede i sociologiju sela, Trg Dositeja Obradovića 8, 21000 Novi Sad, Srbija, Telefon: +38121450 355, E-mail: veselinovic.janko@gmail.com

7 Prof. dr Mirjana Milošević, redovni profesor, Univerzitet u Novom Sadu, Poljoprivredni fakultet, Trg Dositeja Obradovića 8, 21000 Novi Sad, Srbija, Telefon: +381 21450 355, E-mail: mirjana.milosevic9@gmail.com

8 Sara Počuča, M.A., doktorand, Pravni fakultet, Univerzitet u Beogradu, Bulevar kralja Aleksandra, 11000 Beograd, Telefon: + 38163209 523, E-mail: pocucamsara@gmail.com

EP 2014 (61) 1 (211-223) 
